\title{
Erratum to: A Natural Isolate Producing Shikimic Acid: Isolation, Identification, and Culture Condition Optimization
}

\author{
Garima Rawat • Priyanka Tripathi • Firdaus Jahan • \\ R. K. Saxena
}

Published online: 5 May 2013

(C) Springer Science+Business Media New York 2013

\section{Erratum to: Appl Biochem Biotechnol (2013) 169:2290-2302 DOI 10.1007/s12010-013-0150-1}

The original version of this article unfortunately contained a mistake. The accession number of the bacteria is incorrect. The correct accession number should be KC466031.

The online version of the original article can be found at http://dx.doi.org/10.1007/s12010-013-0150-1.

G. Rawat $\cdot$ P. Tripathi $\cdot$ F. Jahan $\cdot$ R. K. Saxena $(\bowtie)$

Department of Microbiology, University of Delhi South Campus, New Delhi 110021, India e-mail: rks.micro2012@gmail.com

R. K. Saxena

e-mail: rksmicro@yahoo.co.in

G. Rawat

e-mail: garima_205@yahoo.com 